\title{
Appropriation of Hindustani Musical Elements in Vocal Parts of Malay Ghazal
}

Chintaka Prageeth Meddegoda, University of Visual and Performing Arts, Colombo, Sri Lanka

chinthakameddegoda@yahoo.co.in

(C) 2016 University of Malaya. All rights reserved.

Malaysian Journal of Performing and Visual Arts, Volume 2, 2016

\begin{abstract}
The main task of this paper is to illustrate how Hindustani musical elements are employed in the vocal lines of Malay ghazal which have been obscured or modified and "Malayized" throughout the past decades. In current Malay ghazal practices known in Johor, a particular singing style called "Parsi" that primarily focused on a specific embellishment of the melodic line could be observed. Another particular element is called "sarigama-singing" (Arshad, 2013; Rahman B., 2012) that refers to melodic ornaments resembling the gamak and taan in Hindustani classical music. The adaptation and its outcome that have been documented in some selected ghazals confirm the existence of a discerning tolerance towards elements detached from their originating cultural environment.
\end{abstract}

This paper discusses stereotypical melodic elements sung by Malay musicians in Malay ghazal. Although various raga elements can be detected in the vocal melodies, these elements are not acknowledged and are not terminologically familiar to Malay ghazal musicians. The detected ragas maintain one tonic, which means that the main fifth (Sa$\mathrm{Pa}$ ) applies as a frame for an entire given melody. The range in which Malay ghazal is sung does not exceed one octave. Nonetheless, the actual starting pitch is somewhat fixed through the fact that early harmoniums could not shift in pitch. Therefore, Malay ghazals are mainly played for a high pitched male or a lower pitched female voice. Male singers performing ghazal may have obtained singing skills from the model of qawwali singers. There is no evidence for it in the reviewed literature. However, the knowledge about these special features that can also be observed in Hindustani ghazal is transmitted orally from one musician to the next (Norihan, 2012-2014). Main methods applied in this study are long term participant observation in the origination and in the host culture of ghazal practices, multi-perspective analysis of musical structures and terminology.

Keywords: Ghazal, Malay ghazal, Hindustani classical music, raga, Parsi theatre

\section{Background and Poetic Renderings of Ghazal}

Historically, the ghazal came to the Malay world from Mughal India and partly from Arabia and Persia. Examining poetic elements in Malay ghazal lyrics may help to verify Indian, Arabian or Persian Malay ghazal poetries. There are some questions that have not yet been addressed in previous theories on the adaptation of pantun and melodies into the Malay ghazal. It was originally a literary genre which was strongly related to 
languages such as Arabic, Persian and more prominently Urdu (Indo-Persian synthesis). Meisami (1998) defines the Arabic ghazal as a "poetry about love, whether incorporated into the qasida or in an independent, brief poem". With reference to the Persian ghazal, Bausani (1965) notes that it may have a content denoting love, spring, wine, or God but the formal structure needs to remain unchanged, e.g., the structure needs to maintain a certain length, rhyme scheme and tak hallus (the poet's pen name) in the final (ending) line (Bausani, 1965:1033b). Furthermore, Regula Qureshi (1990: 458) describes the Urdu ghazal as "highly formalized, stylized, and rich in metaphor, the [Urdu] ghazal serves the expressions of emotion and cognition in a rarefied, universalized, yet intimate way through its main subject: love, both human and spiritual." Originally the concept of the ghazal was "love", initiated in Arabian cultures and later travelling to Persia (Bausani 1960:1028ff).

From the $16^{\text {th }}$ century onward, the ghazal came to India along with the Persians and was developed in Urdu, a language nurtured through Indo-Persian cultural interaction. Chanted ghazal verses were understood as a graceful and noble linguistic expressive art among aristocrats in Mughal India that generally included vocalized conversations which permeated the education of the high-class Muslim society in India. The poetic symposium called 'mushaira' is a sort of competitive platform where shayars (poets) presented the ghazal to an audience of nobles and aristocrats; likewise, the shayars were mostly nobles and aristocrats. In a mushaira, ghazals were presented by male shayars in rhythmic speech (takht ul lafz) as well as in chanting (tarannum). The ghazal verses written in the form of mystic inspirations were adapted into qawwali ${ }^{1}$ singing that used to be performed in front of Sufi shrines at mosques. Ghazals narrating various themes that are subjected to romance were sung by courtesans (tawaif) who entertained nobles and aristocrats who used to gather in private mansions called havelis (in India and Pakistan) and in salons (mehfil/mujra). After significant British suppression (1857) of the deep-rooted Muslim aristocracy throughout the upper Gangetic plain and in central India, the ghazal was adopted by the middle-classes residing in those areas. Subsequently, it was preferred by the general public throughout the region.

The Urdu ghazal might also have travelled to Southeast Asia as an accompanying component of Sufi mysticism that flourished during and after the period of the Mughal Empire. Previous studies (Braginsky \& Suvorova, 2008) suggest that there could have been a possibility for the emergence of the Urdu ghazal with the Sufis who were engaged in spreading the Islamic faith in the Malay world. However, the Malay ghazal differs from the Urdu ghazal in various aspects. With reference to the ghazal as a poetic genre, it is important to take a closer look at the major poetic principles and elements that were used in both Malay and Urdu ghazals. Table 1 shows the concept of ghazal poetry has changed in Malaysia with some inclusions and exclusions.

Urdu lyrics were the very first elements excluded from the Malay ghazal. Urdu was not understood by the aristocratic society of Malaya though they might have admired the language including the culture of which it was associated. Rohaya Ahmad (2007) mentions two remarkable teachers who taught ghazal in Malaya, mainly in Johor, at the beginning of the $20^{\text {th }}$ century, namely Sheikh Abdullah and Ustad Alfa. The ghazal history underpins Islamic practices. Upper-class Malays may have appreciated ghazal 
poetry due to their Islamic origin as well as due to the subjects associated with Islamic mysticism and love stories such as Laila Majnun.

In a previous study, the author points out (Meddegoda, 2015) that many Malay syair ${ }^{2}$ and hikayat are adaptations of Urdu and early Indo-Persian literary works, which were widely influenced by Sufism and Islamism in general. An essential feature of the Malay ghazal is the appropriation of Malay traditional pantun verses ${ }^{3}$ that are detached from the Urdu literary adaptations. Malay pantuns are basically sung to express the beauty of nature and emotions like love from various perspectives and they may have didactic purposes. Nevertheless, Malay pantuns can be closer to qasida than Urdu ghazal in some aspects. Qasida is described as a laudatory, elegiac, or satiric chanted poem. ${ }^{4}$

Qasida chanting became a common practice in the Malay world since oversea travel increased and the flow of people became easier, as well as with the use of modern media (Rasmussen, 2010: 78-79). It can be stated that qasida chanting and ghazal practices emerged in the same time period (between the end of the $19^{\text {th }}$ and the beginning of the $20^{\text {th }}$ century) and could have influenced each other in terms of special singing styles cultivated through the input of other cultures, their languages, and their poetic articulations, derived from different directions. ${ }^{5}$

The formal structure of the ghazal poetry found in some literature shows few similarities with the traditional Malay pantun and the Urdu ghazal. The minimum number of verses in a Malay ghazal should be five and the normal maximum is 12 verses. A Malay pantun needs to consist of at least two lines known as "pantun dua kerat" and a maximum of 16 lines called "pantun enam belas kerat". 6 Table 1 below shows poetic elements in the Urdu ghazal and in the Malay ghazal.

\begin{tabular}{|l|l|l|}
\hline Poetic Elements Used in Urdu Ghazal & $\begin{array}{l}\text { Term in } \\
\text { Urdu }\end{array}$ & $\begin{array}{l}\text { Term Used in } \\
\text { Malay Ghazal } \\
\text { (Pantun) }\end{array}$ \\
\hline $\begin{array}{l}\text { Rhymed verses (couplet): A sher is a couplet poem of } \\
\text { two lines. Each couplet embodies a single thought and is } \\
\text { self-entailed. The plural of sher is ashaar. A sher is also } \\
\text { called 'bait' (bay-t). }\end{array}$ & sher & pantun dua kerat \\
\hline Another term for sher & bait & \\
\hline $\begin{array}{l}\text { The best sher in a ghazal. 'bait-ul-ghazal' also known as } \\
\text { husn-e-ghazal. }\end{array}$ & bait-ul-ghazal & \\
\hline A line of a couplet or verse is called a misra. ${ }^{9}$ & misra & misra-e-oolaa \\
\hline The first line of a sher. & misra-e-saanii & \\
\hline The second line of a sher. & bahr/beher & \\
\hline $\begin{array}{l}\text { Metre: Both lines of a sher must have the same metre. All } \\
\text { ashaar in a ghazal must have the same metre (bahr). }{ }^{10}\end{array}$ & $\begin{array}{l}\text { arkaans } \\
\text { Dummy meaningless words (non-lexible syllables) that } \\
\text { define the length of a sher (poetry). The basic purpose of }\end{array}$ & \\
\hline
\end{tabular}




\begin{tabular}{|c|c|c|}
\hline $\begin{array}{l}\text { which is to specify the places of long and short syllables } \\
\text { in an actual word }{ }^{11} \text {. }\end{array}$ & & \\
\hline $\begin{array}{l}\text { Rhyme proper: The rhyming pattern of the word(s) just } \\
\text { before the radiif at the end of the line in a sher. This is a } \\
\text { necessary requirement, followed even in the absence of } \\
\text { other rules }^{12}\end{array}$ & qafiya & \\
\hline $\begin{array}{l}\text { End-rhyme: Word or phrase that is repeated at the end of } \\
\text { the second line in every sher. The same word }(\mathrm{s}) \text { are } \\
\text { repeated. Both lines of the matlaa end in the radiif }{ }^{13} \text {. }\end{array}$ & radif & \\
\hline $\begin{array}{l}\text { Opening verse (first couplet): this is the first sher of a } \\
\text { ghazal, and both lines of the sher must end in the radiif. } \\
\text { Usually a ghazal has only one matla. }{ }^{14}\end{array}$ & matla & pembayang \\
\hline $\begin{array}{l}\text { If a ghazal has more than one matla, then the second one } \\
\text { is called 'matlaa-e-saanii. }{ }^{15}\end{array}$ & $\begin{array}{l}\text { matlaa-e- } \\
\text { saanii/ husn- } \\
\text { e-matla }\end{array}$ & \\
\hline $\begin{array}{l}\text { Final verse (second couplet): The sher in which the } \\
\text { takhallus is included is called the maqta. It is the last sher } \\
\text { of the ghazal }{ }^{16} \text {. }\end{array}$ & maqta & maksud \\
\hline $\begin{array}{l}\text { Poet's pen-name: A shayar (poet) usually had a pen- } \\
\text { name under which he wrote. The pen-name is called } \\
\text { 'takhallus' (takh-ul-lus) }{ }^{17} \text {. }\end{array}$ & takhallus & \\
\hline Registers of frequent use for example e 'of' and -o 'and' & izafats & \\
\hline Rhythmic speech & tah tul lafz & \\
\hline Chanting style & tarannum & tarannum \\
\hline Competitive poetic symposium & mushaira & \\
\hline Collected works of a poet ${ }^{18}$ & diwan & \\
\hline Composer of the poem & shayar & \\
\hline Poems & shayari & shair \\
\hline
\end{tabular}

Table 1. Poetic elements used in the Urdu ghazal and in the Malay pantun Malay ghazal (pantun). The empty places indicate either a missing term or the use of the same term if known to a speaker who understands Urdu.

An example of the Urdu ghazal shows an important pattern of the verse structure (mujtas, see Table 2), and rhyme position (radif, bold letters), throughout the poem of Asadullah Khan Ghalib noted and translated in Kanda (1992: 153):

\section{Urdu}

(Composed by Asadullah Khan Ghalib)

Koi Umeed bar nahin aati,

Koi surat nazr nahin aati. 
Maut ka ek din maayen hai,

Neend kyon raat bhar nahin aati.

Aage aati thi haal-e-dil pe hansi,

Ab kisi baat par nahin aati.

Jaanta hun sawaab-e-taait-o-zuhd,

Par tabiat idhar nahin aati.

Hai kuch aisi hi baat fo chup hun,

Warna kya baat kar nahin aati.

Daagh-e-dil gar nazr nahin aata,

$\mathrm{Bu}$ bhi ai chaaragar nahin aati.

Ham wahaan hain jahaan se ham ko bhi,

Kuchh hamaari khabar nahin aati. ${ }^{19}$

For illustration, here is the part of a pantun ${ }^{20}$ used in the Malay ghazal Nasib Badan. The rhyme is not repetitive throughout the poem and different in meaning.

\section{Malay}

Nasib badan lagu asli

Dari dahulu sudah ternama.

Saya ini ibarat tali

Tak ada rotan akar berguna.

Nasib badan lagu asli

Dari dahulu sudah terbilang.

Kalau pandai menjaga diri

Kemana pergi tidak terbuang.

\begin{tabular}{|l|l|l|}
\hline & Urdu Ghazal lyrics & Malay Pantun \\
\hline Origin & $12^{\text {th }}$ century & $\begin{array}{l}\text { Unknown. Sources available since } \\
\text { the } 15^{\text {th }} \text { century. }\end{array}$ \\
\hline Class & $\begin{array}{l}\text { Used by the upper class before } 1857 . \\
\text { Later middle-class. }\end{array}$ & 'Folk literature' \\
\hline Structure & $\begin{array}{l}\text { Basic structure known as mujtas, a large } \\
\text { number of different structures }\end{array}$ & $\begin{array}{l}\text { abab, abcabc, abcdabcd and some } \\
\text { others (according to this study) }\end{array}$ \\
\hline Genres & $\begin{array}{l}\text { Qawwali, ghazal art song formats, } \\
\text { tarannum singing in musha'ira, singing } \\
\text { in Shia Majlis functions }\end{array}$ & $\begin{array}{l}\text { Malay ghazal, Malay pop song, } \\
\text { zapin, dongdang sayang, joget, } \\
\text { asli, theatre songs. }\end{array}$ \\
\hline
\end{tabular}

Table 2. Various cultural elements in Malay ghazal lyrics (Liaw, 2013; Kanda, 1992). This table shows that Urdu ghazal and Malay ghazal cannot be compared regarding their text structures.

The differences of incorporating or inserting lyrics into a musical context between the Urdu and the Malay ghazal are obvious. While the Urdu ghazal lyrics were applied by 
the upper- and middle-classes, the Malay pantun is regarded as folk literature (Liaw, 2013). Urdu ghazal lyrics are confined to certain genres, especially in a spiritual context and in elitist entertainment. The Malay pantun is used in many other performing arts crossing social boundaries.

The exclusion and inclusion of lyrics in the Malay ghazal can, therefore, indicate that the Malay pantun may have been differentiated in order to accommodate the spiritual meaning (Amin, 1979) and the openness of entertainment events in the context of the Malay community of Johor. Urdu ghazal lyrics are rarely translated into Malay or used in Malay ghazals according to the musicians who perform this genre (Jafar, 2013; Norihan, 2012-2014).

\section{Vocal Renderings in Malay Ghazal}

The literature on adaptation patterns of other cultures by Malays, such as eating, architecture, dress, and communication patterns, are studied and used to infer some Malay behavioural patterns which might have been the grounds for an acculturation process of some Indian cultural elements in the Malay world and possibly some Malay elements in the Indian world.

Some scholars explore the coherence between Malay music and Malays' behavioural patterns and nature in general Malay life. Benjamin (2011), for instance, compares eating habits with musical renderings:

Just as a polite Melayu diner will sit on the floor with the food far from the mouth, break off a yet smaller piece from the already small piece of fish or meat, ball it up with rice using only three fingers of the right hand, and then move it to the mouth so also will a skilful Melayu singer or violinist move from one note to another by a quite devious, melismatically elaborated, route (p. 10).

Malay ghazal singing may, to some extent, bear a resemblance to Islamic tarannum recitation principles in the past. The Malay tarannum reciters obtained their training from Arab experts whose tarannum recitation was based on some maqamat. The call for prayers and other Islamic vocal practices are examples of which Islamic recitations must likely have tremendously influenced the melodic perception and aesthetic preferences among the Malays. Since Malays are Muslims by birth ${ }^{21}$, they become familiar with tarannum recitations through family members and subsequently learn Islamic recitation in school and other Islamic education centres. The musicality Malay musicians develop through their Islamic environment, in which Islamic recitation practices are regularly carried out, may guide them through music practices as well. In the Malay world, tarannum means only "quranic recitation" based on a few selected maqamat.

However, tarannum is defined by Farmer (1965: 1073) as "unpretentious psalming varied and embroidered by the singer". In oral history, the tarannum is a kind of chant that refers to "a monophonic style of singing or recitative in free rhythm ... used as a heightened speech-song ..." (Brakeley, 1949:210). Farmer's definition is quite similar 
to the Malays' interpretation. However, Malay tarannum practitioners do not accept themselves as singers, since they looked at the tarannum vocal sound through a spiritual perspective rather than a musical perspective. Regula Qureshi (1969: 448) describes how the tarannum is chanted among the Indian Muslim communities of North India. She also refers to Gosvami who said that the melodic organization of tarannum falls within the gamut of North Indian light classical and folk music, showing certain basic features of both. He speaks about the use of two superimposed corresponding tetrachords (Gosvami, 1961:282). Regula Qureshi recognizes the tarannum singing in India through the viewpoint of Hindustani music. Tarannum singing might have reached India from Arabia via Persia. Therefore, the maqam framework of tarannum model tunes has remained unnoticed in its practices in India. Qureshi (1969) has divided the melodic material of tarannum practices in North India into two different categories, stock tunes and individual tunes. Stock tunes are melodies of a recognizable pattern and outline, whereas individual tunes are those based on similar overall melodic ingredients but significantly differ in individual outlines and tonal groupings (Qureshi, 1969:433). The stock tunes may be the framework of the frequently used tarannum melodies in which ghazal verses were set and recited by the poets in mushairas. Qureshi's definition of tarannum is "solo chanting of poems" (1991: 176) and various Urdu poems can be sung in the style of tarannum.

In the Malayan history of Islam, it is evident that some Indian Sufis and musicians such as Ustad Sheikh Abdullah and Ustad Alfa (Rohaya Ahmed, 2007) were involved in Islamic cultural practices. However, it needs further serious studies to find out the connection between the Hindustani tarannum (mainly solo chanting of ghazals) and early practices of tarannum in Malaya.

\section{Melodic and Rhythmic Features of Vocal Parts in Malay Ghazals}

The following discussion is based on selected sections of the ghazals entitled Sri Mersing, Pak Ngah Balik, Nasib Badan, Sri Muar, and Sayang Musalmah. ${ }^{22}$ Some ghazal melodies were later adapted into other popular song genres such as asli or inang. However, they were first composed as ghazals (Norihan, 2016). Other ghazal recordings have been given due attention as well. The transcriptions ${ }^{23}$ provided are strictly bound to each respective recording and do not represent a typical performance or a general understanding of the exact ways of reproduction. There are many versions of ghazals that may differ in some structural features. However, this overview can give a summary of the unique attributes of each ghazal that are also be found in other versions.

Musical transcriptions of vocal melodies of the ghazals Sri Mersing, Pak Ngah Balik, Nasib Badan, Sri Muar and Sayang Musalmah are provided by the author and the lyrics of each vocal melody are correspondingly specified immediately below the melodic lines of each transcription. These lines are separated according to their musical phrase meaning that is inherently given through its 'melodic grammar'. Each line finishes on a phrase ending that represents a unique feature of the respective ghazal. Most obviously, long rests signify the separation of musical lines. The range in which Malay ghazal is sung does not exceed one octave. But, the actual starting pitch is somewhat fixed through the fact that early harmoniums could not shift in pitch (Meddegoda, 2013). 
In the vocal transcription, the vocal lines are shown as separated melodic phrases. Many of those phrases that refer to the adaptation of the harmonium also apply to the melodic behaviour of the vocal parts in the Malay ghazal. In the following, melodic and rhythmic features of vocal parts will be taken into close consideration and discussed.

Regarding the general formal structure, a few features that characterize vocal renderings in Malay ghazals can be summarized. These are listed below in Table 3.

\begin{tabular}{|c|c|c|c|c|c|c|}
\hline \multirow[t]{2}{*}{$\begin{array}{l}\text { Typical structure of } \\
\text { ghazal Johor }\end{array}$} & \multirow[t]{2}{*}{$\begin{array}{l}\text { Signs } \\
\text { applied } \\
\text { according } \\
\text { to melodic } \\
\text { similarities }\end{array}$} & $\begin{array}{l}\text { Intra-diversity } \\
\text { of the formal } \\
\text { structure } \\
\text { within } \\
\text { selected } \\
\text { ghazal } \\
\text { examples }\end{array}$ & & & & \\
\hline & & Sri Mersing & $\begin{array}{l}\text { Pak } \\
\text { Ngah } \\
\text { Balik }\end{array}$ & $\begin{array}{l}\text { Nasib } \\
\text { Badan }\end{array}$ & $\begin{array}{l}\text { Sri } \\
\text { Muar }\end{array}$ & $\begin{array}{l}\text { Sayang } \\
\text { Musal- } \\
\text { mah }\end{array}$ \\
\hline $\begin{array}{l}\text { Introductory } \\
\text { instrumental piece }\end{array}$ & & $4 / 4$ & $\begin{array}{l}\text { free } \\
\text { metric } \\
\text { (taksim) }\end{array}$ & $6 / 8$ & $6 / 8$ & $4 / 4$ \\
\hline Stanza 1 & A1-1 & $\sqrt{ }$ & $\sqrt{ }$ & $\sqrt{ }$ & $\sqrt{(1 / 2)}$ & $\sqrt{ }$ \\
\hline Stanza 1 repeated & A1-2 & $\sqrt{ }$ & $\sqrt{ }$ & $\sqrt{ }$ & $\sqrt{(1 / 2)}$ & $\sqrt{ }$ \\
\hline Stanza 2 & B1-1 & $\sqrt{ }$ & $\sqrt{ }$ & $\sqrt{ }$ & $\sqrt{ }$ & $\sqrt{ }$ \\
\hline Stanza 2 repeated & B1-2 & $\sqrt{1}$ & $\sqrt{ }$ & & & \\
\hline Stanza 3 & A2-1 & $\sqrt{ }$ & $\sqrt{ }$ & $\sqrt{ }$ & $\sqrt{(1 / 2)}$ & $\sqrt{ }$ \\
\hline Stanza 3 repeated & A2-2 & $\sqrt{ }$ & $\sqrt{ }$ & $\sqrt{ }$ & $\sqrt{(1 / 2)}$ & $\sqrt{ }$ \\
\hline Stanza 4 & B2-1 & $\sqrt{ }$ & $\sqrt{ }$ & $\sqrt{ }$ & $\sqrt{ }$ & $\sqrt{ }$ \\
\hline Stanza 4 repeated & B2-2 & $\sqrt{ }$ & $\sqrt{ }$ & $\sqrt{ }$ & $\sqrt{ }$ & $\sqrt{ }$ \\
\hline $\begin{array}{l}\text { Concluding } \\
\text { instrumental piece }\end{array}$ & & $4 / 4$ & & & $6 / 8$ & \\
\hline
\end{tabular}

Table 3. Some basic features of the structure of selected ghazals and the order of different parts of the pantun(s), which are variously extended through repetitions and singing syllables in musical stanzas. The letters indicate a musical rather than a textual relationship.

The harmonium always guides the tetrachord from which the vocal part begins; subsequently, its melody continues even after the vocal phrase has ended. The harmonium phrases always accompany the vocal phrases, but they do not attempt to imitate the vocal melody (Figure 1). 


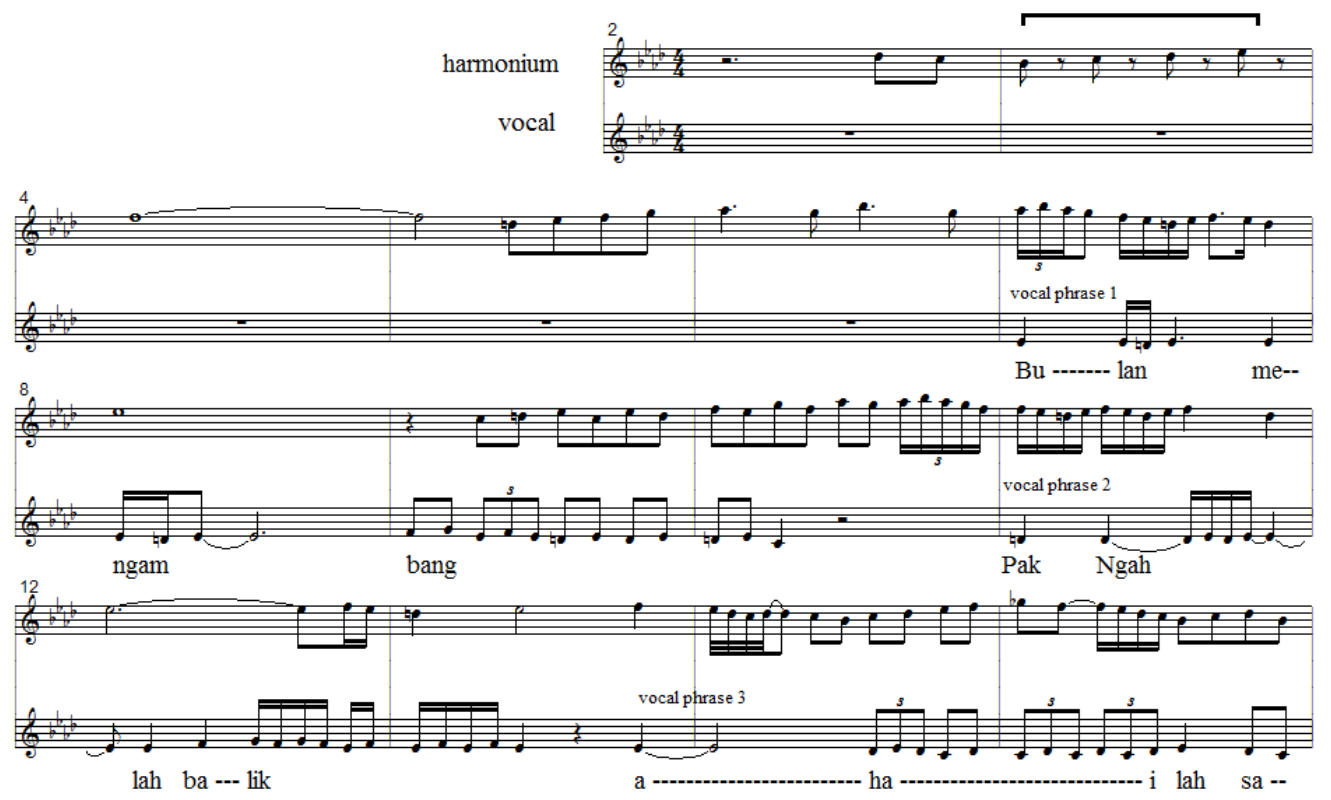

Figure 1. The first stanza (A1-1) of the ghazal Pak Ngah Balik. Both harmonium (above) and vocal lines (below) are represented together (transcription by the author).

Habitually, the vocal phrases of selected ghazals do not start on the emphasized beat of the bar and remarkably, they end after or before the first and most emphasized beat of a bar (see Figure 2).
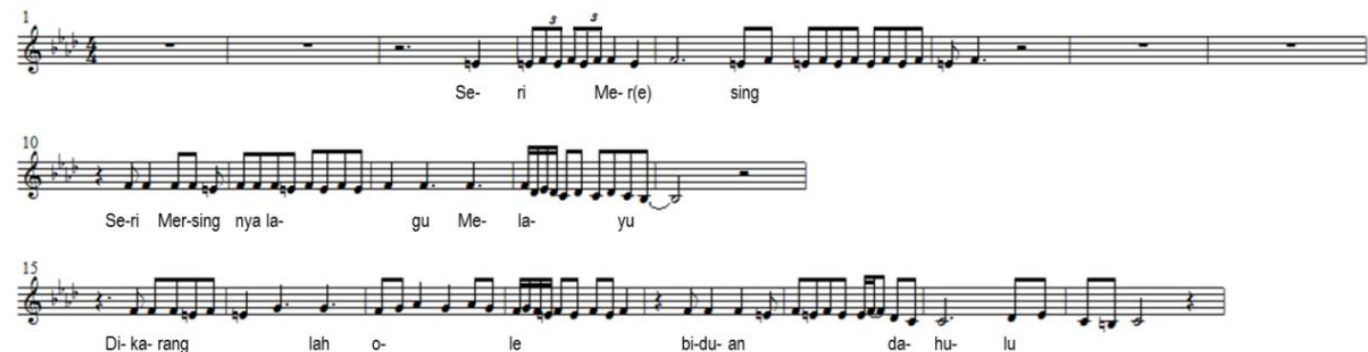

followed by a rest of 12 bars

Figure 2. The first stanza of Sri Mersing (A1-1) demonstrates that the beginning and ending of a vocal phrase results in unemphasized units of the bar. The following 12 bar rest is important to the entire ghazal structure (Meddegoda, 2015: 106) (transcription by the author).

The vocal lines can be of different length within a stanza. Nevertheless, the vocal phrases of similarly structured pantuns, i.e. the first and third (A, see Table 3) as well as the second and fourth (B, see Table 3 ) stanzas can have vocal lines similar to their individual length. 
The range of vocal lines is often limited to the fifth. However, it can be further elaborated in repeated sections to extend up to an octave.

Sung phrases are always longer than their pivotal ${ }^{24}$ text depending on the number of syllables. The pivotal text is extended through repetitions and additional words during singing in an improvisatory manner. The singer can start at any time within the time frame set for the vocal part. This freedom of choice in starting to sing makes vocal phrases become different in length though the general metric framework is maintained. However, irrespective of a specific length of the vocal phrase, the singers always manage to confine each vocal phrase within the respective underlying harmonium melodic phrase, which may work as a guiding timeline. This feature can be noticed because the harmonium melodic phrases are mostly of similar individual length with the harmonium melodic phrases of the corresponding stanzas (A and B). The harmonium phrases are played in an improvisatory manner whilst maintaining the framework of shifting tonics within the stanzas.

Various raga elements can be detected in the vocal melodies of Malay ghazals. These raga elements are neither thought about nor known at all to the Malay ghazal musicians, but they can still be traced in the vocal melodies. Most of the present-day Malay ghazal singers are admirers of Hindi film songs. Hence, they tend to listen and sometimes perform these songs that are mainly $20^{\text {th }}$ century releases. Some Malay ghazal singers understand the old Hindi film songs as a Hindustani ghazal and the new ones as Bollywood pop. However, film songs which were sung by Lata Mangeshkar, Asha Bhosle, Kishor Kumar, Mohammed Rafi, Manna Dey, and Mukesh are considered as Hindustani oldies and Hindustani ghazals. Malay ghazal renderings may also reflect some Hindustani musical elements that have influenced the musicality of Malay musicians who listen to and practice Hindi film songs. Despite this, there is very little possibility that the Malays have obtained in-depth knowledge of raga and the meter of Hindustani music through listening and imitating Hindi film music.

Some elements of $\operatorname{ragas}^{25}$ are detected in ghazal melodies. Here only the closest ragas are mentioned (see Table 4). Ragas maintaining one tonic were detected, i.e. the main fifth $(\mathrm{Sa}-\mathrm{Pa})^{26}$ applies as a criterion for the entire melody. In finding possible maqam connections, different tonics often have to be considered since the tonics for various tetrachords can shift.

\begin{tabular}{|l|l|l|l|}
\hline \multicolumn{2}{|l|}{ Title of the Ghazal } & Traces of Raga & Traces of Maqamat \\
\hline Sri Mersing & First and third stanza & Kirwani (Figure 3) & Hijaz with nahawand \\
\hline & $\begin{array}{l}\text { Second and fourth } \\
\text { stanza }\end{array}$ & Kirwani (Figure 4) & $\begin{array}{l}\text { Ajam (jiharkah) return } \\
\text { to hijaz }\end{array}$ \\
\hline $\begin{array}{l}\text { Pak Ngah } \\
\text { Balik }\end{array}$ & First and third stanza & $\begin{array}{l}\text { Bhairavi and mishra } \\
\text { bhairavi (Figure 5) }\end{array}$ & Kurd \\
\hline & $\begin{array}{l}\text { Second and fourth } \\
\text { stanza }\end{array}$ & $\begin{array}{l}\text { Bhairavi and mishra } \\
\text { bhairavi (Figure 6) }\end{array}$ & $\begin{array}{l}\text { Jiharkah (intro is hijaz } \\
\text { kar kurd) }\end{array}$ \\
\hline
\end{tabular}


Chintaka Prageeth Meddegoda

\begin{tabular}{|l|l|l|l|}
\hline Nasib Badan & First and third stanza & $\begin{array}{l}\text { Ashawari, and kirwani } \\
\text { (Figure 7) }\end{array}$ & Nahawand and kurd \\
\hline Sri Muar & $\begin{array}{l}\text { Second and fourth } \\
\text { stanza }\end{array}$ & $\begin{array}{l}\text { Ahir-bhairav } \\
\text { (Figure 8) }\end{array}$ & Jiharkah \\
\hline & $\begin{array}{l}\text { Second and fourth } \\
\text { stanza }\end{array}$ & $\begin{array}{l}\text { Alhaiya bilawal } \\
\text { (Figure 10) } \\
\text { (Figure 9) }\end{array}$ & $\begin{array}{l}\text { Very short nahawand, } \\
\text { then again ajam } \\
\text { (jiharkah) }\end{array}$ \\
\hline $\begin{array}{l}\text { Sayang } \\
\text { Musalmah }\end{array}$ & $\begin{array}{l}\text { First and third stanza } \\
\text { Stanza }\end{array}$ & $\begin{array}{l}\text { Bhairavi, nat-bhairav, } \\
\text { kirwani,adana, jounpuri, } \\
\text { ramkali (Figure 11) }\end{array}$ & Hijaz \\
\hline $\begin{array}{l}\text { Tambak } \\
\text { Johor }\end{array}$ & $\begin{array}{l}\text { First and third stanza } \\
\text { Kirwani, adana, darbari } \\
\text { kanada } \\
\text { (Figure 12) }\end{array}$ & $\begin{array}{l}\text { Kirwani (Figure 20 } \\
\text { Stanza }\end{array}$ & Hijaz with nahawand \\
\hline
\end{tabular}

Table 4. Shadows of ragas and fragments of maqamat in vocal melodies of selected Malay ghazals detected by Meddegoda (ragas) and Jähnichen (maqamat, Jähnichen, 2014). The experience of interpreting melodic features as ragas or as maqamat depends strongly on the cultural experience of the listeners.

Examining the tone groups applied, some features of dominating ragas can be detected in the Malay ghazal, as shown below.

Raga kirwani:
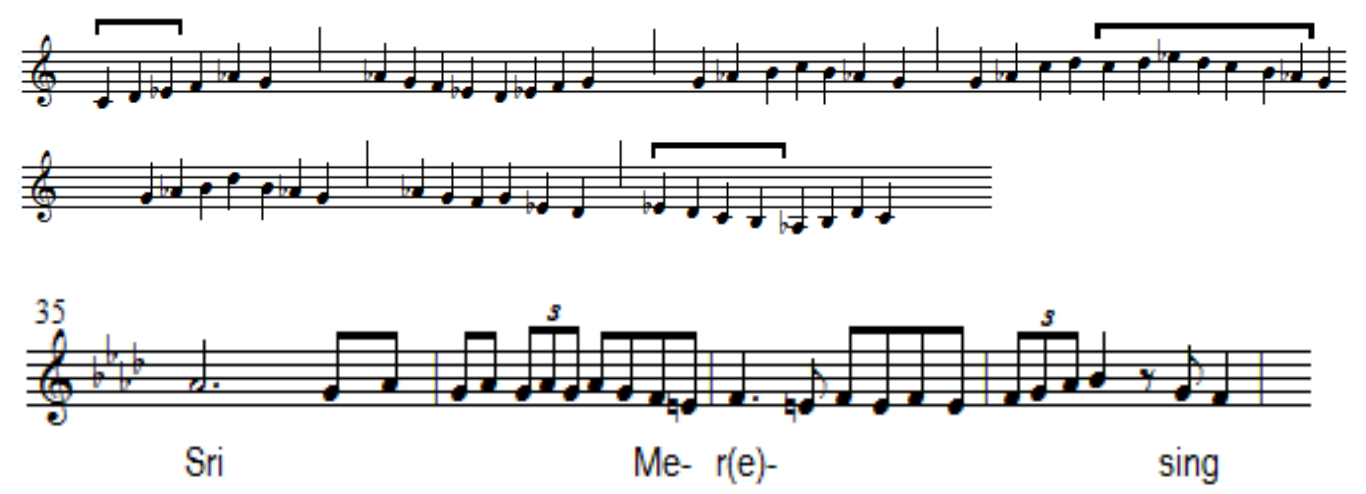

Figure 3. Outlines of the main melodic features in raga kirwani (transposed into $\mathrm{Sa}=\mathrm{c}$ ) and an excerpt from the first stanza of Sri Mersing (A1-2) with $\mathrm{Sa}=\mathrm{f}$ (transcription by 
the author). Raga kirwani is rooted in Carnatic music and was adapted into Hindustani music. This raga allows for free applications of its features and is often used in semiclassical genres of Hindustani music.

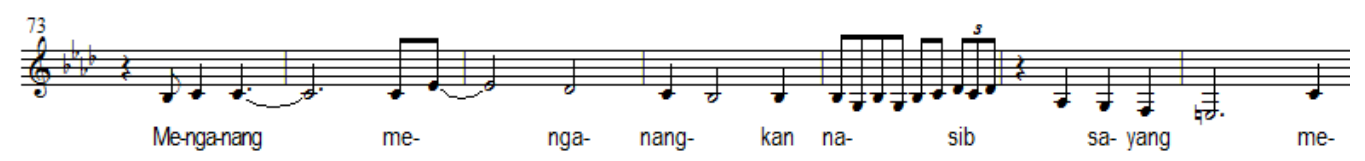

Figure 4. Excerpt from the second stanza of Sri Mersing (B1-1) (transcription by the author).

Raga bhairavi:

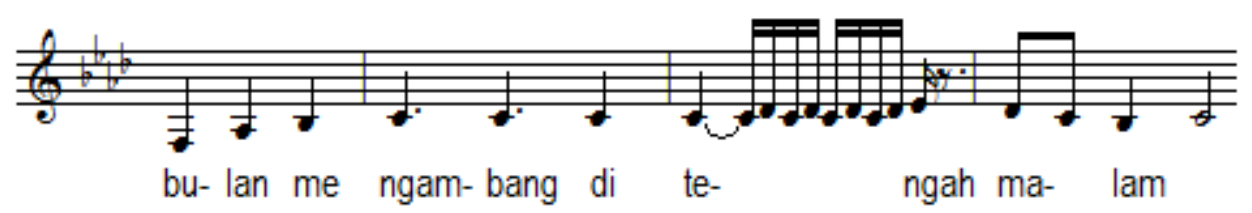

Figure 5. Excerpt from the first stanza of Pak Ngah Balik (A1-1) (transcription by the author).

Raga mishra bhairawi:

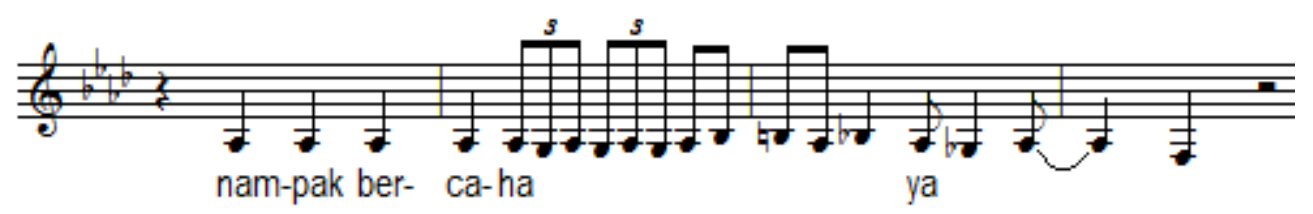

Figure 6. Excerpt from the second stanza of Pak Ngah Balik (B1-1) (transcription by the author).

Raga ashawari:

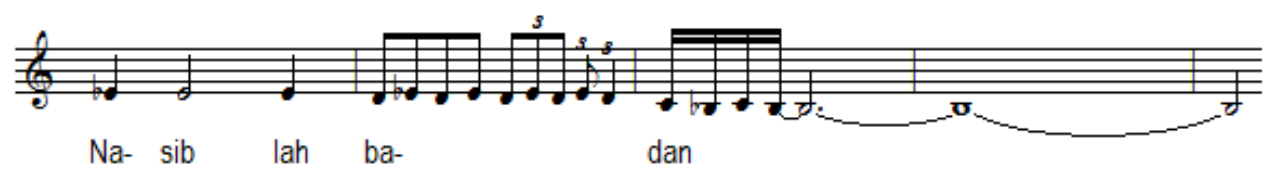

Figure 7. Excerpt from the first stanza of Nasib Badan (A1-1). 
Raga ahir-bhairav:

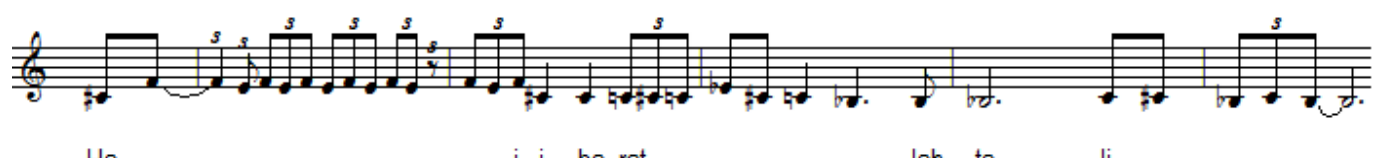

Ha-

i i- ba- rat

lah ta- li

Figure 8. Excerpt from the second stanza of Nasib Badan (B1-1) (transcription by the author).

Raga shuddha bilawal:

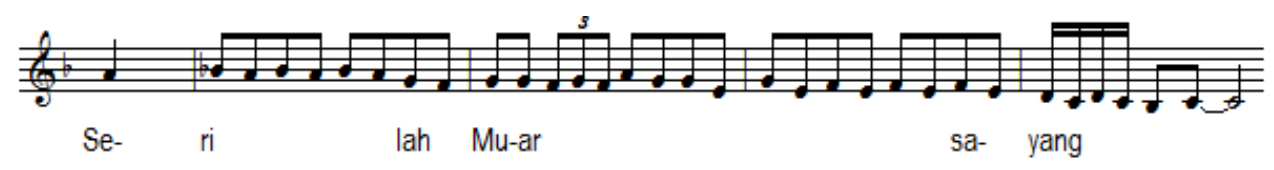

Figure 9. Excerpt from the first stanza of Sri Muar (A1-1) (transcription by the author).

Raga ahir-bhairav:

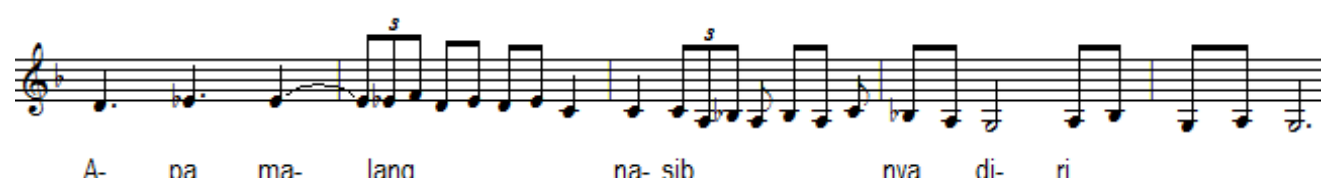

A- pa ma- lang na- sib nya di- ri

Figure 10. Excerpt from the second stanza of Sri Muar (B1-1) (transcription by the author).

The most prominent traces of raga in Malay ghazals are shown in Figures 3 to 10 above.

In addition to the dominating raga elements, a number of other raga fragments can be detected in any selected Malay ghazal, as shown in the transcription of Sayang Musalmah in Figures 11 and 12. 


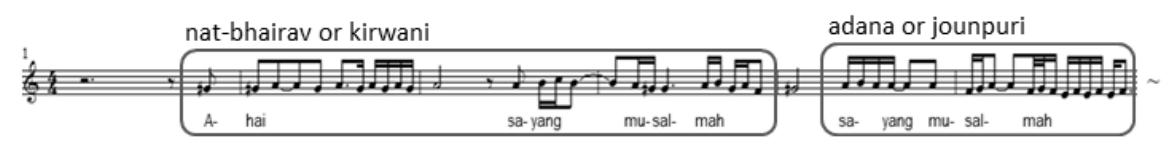

kirwani
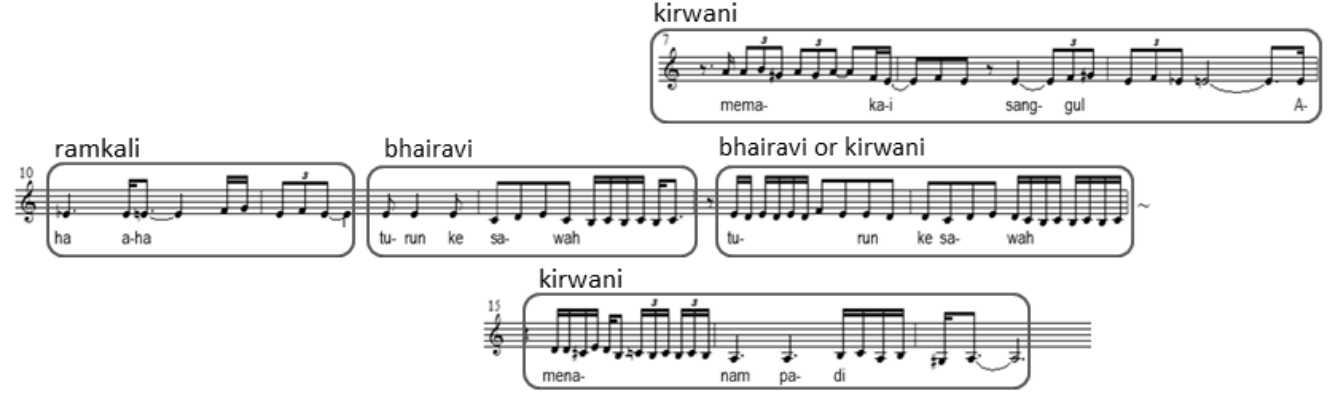

Figure 11. The first stanza of Sayang Musalmah (A1-1) shows a few fragments of different ragas (transcription by the author).

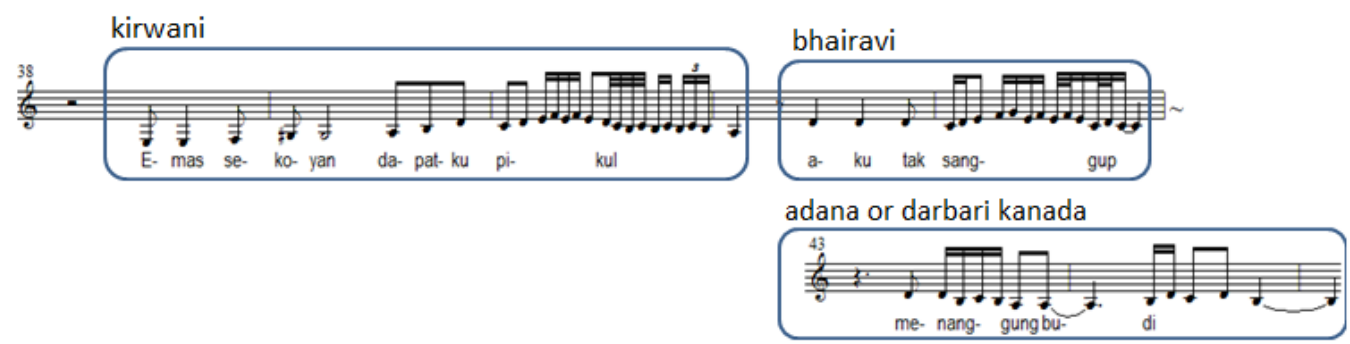

Figure 12. The second stanza of Sayang Musalmah (B1-1) shows a few fragments of different ragas (transcription by the author).

While learning Malay ghazal singing at the ghazal class in ASWARA, the author was taught a specific aspect of vocal embellishment called Parsi, which is sung in the Malay ghazal. According to the teacher, the term "Parsi" is used to designate a specific Hindustani melody technique or embellishment (as seen in the transcriptions above). In an interview, the most eminent harmonium player in Johor, Johari Arshad (2013: ARCPA2167 \& ARCPA2171) ${ }^{27}$, stated that the "Indian way of Sarigama singing is called Parsi". The term Sarigama is similar to the term Sargam in current Hindustani music. Sargam connotes the Hindustani solfeggio, i.e. Sa, Re, Ga, Ma, Pa, Dha, Ni, and Sa. Johari Arshad demonstrated "Sarigama singing" consistent with his perception by singing a melodic piece that is similar to the Hindustani taan and alap singing on the vowel "a". Malay musicians may not mean Persian singing when saying Parsi, but most probably the word is used to denote a Hindustani singing style with its typical melodic shapes or embellishments, e.g. gamak, murkhi and khatka which are sung in a faster tempo. Rohaya Ahmad (2007) describes Parsi with the following words: "The technical term meant for Parsi-Hindustani singing is mostly faster and often a tremolo" [Istilah teknikal dalam ghazal yang bercorak lagu Parsi-Hindustan yang trillnya lebih cepat dan kerap].Nevertheless, the term Parsi might have been adapted from the term Parsi theatre since early Malay musicians experienced this kind of singing through Hindustani music performed in Parsi theatre ${ }^{28}$ practices in the Malay world. They might have imitated a 
Hindustani way of singing by naming it "Parsi". In the ghazal class, the author of this paper was told to sing the first line of the second and fourth stanza of Nasib Badan in a simple way, then, when the same line is repeated, it should be sung by applying "Parsi" (compare Figure 13 with Figure 14).

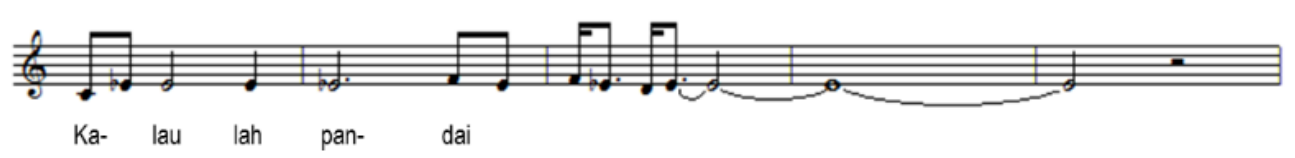

Figure 13. Nasib Badan, Fourth stanza (B2-1). (Transcription by the author).

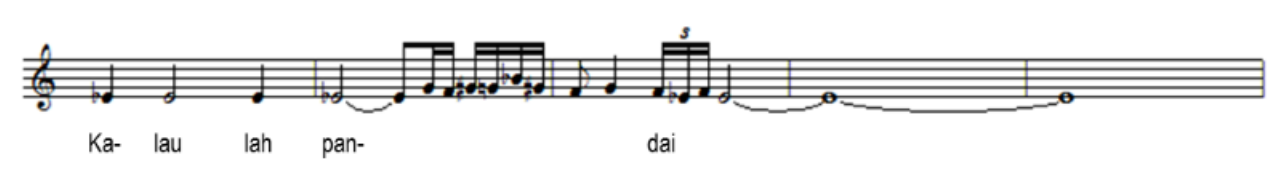

Figure 14. Nasib Badan, Repetition of fourth stanza (B2-2). (Transcription by the author).

Based on the literature reviewed and the observations of Malay musicians, the early forms of ghazal practiced in Malaya were tremendously modified by Haji Musa bin Yusof (Pak Lomak) during the mid-20 2 th century in Johor. Due to the fact that Malay ghazals have been broadcasted since this period, the perception of Malay ghazals among Malays on its overall style has been perpetuated with unavoidable modifications. Besides, ghazal education was centred on recommendations for practicing and on comments on the history of the ghazal made by Pak Lomak. Based on his musical background, Pak Lomak pointed out some important singing techniques which Malay ghazal singers should improve through training. He described these techniques and methods in a handwritten manuscript dated $17^{\text {th }}$ January 1953. This document was written as a sort of marking scheme to be followed by the judges in a Malay ghazal competition. These singing techniques and methods are further explored and described in the thesis of Rohaya Ahmed (2007: 92-93) as follows:

- Masuk lagu enters the song [how to approach the metric frame];

- Mengalun lagu 'heave' the song [develop the emphasized sequences of the melody];

- Mematah lagu derives song [transit from repeating parts];

- Merenek lagu Improvising/shaping the song melodically;

- Mati lagu atau hujung lagu finish a song [shape ending phrases];

- Tal or time [keeping the entire meter];

- Seni kata lagu lyrical song [bringing out the meaning of the words]; and

- Suara penyanyi singing voice [voice quality, 'sweeten the voice']. 
The list above does not include detailed information on how the vocal sound, dynamics, and melodic shapes should be produced in Malay ghazal singing.

A few patterns of frequently used melodic shapes are seen through vocal transcriptions. The most obvious are:

1. Oscillations between two neighbouring tones on one syllable in varying speed. This oscillation is not directly a vibrato or just melismatic singing but rather it has a unique quality. The adjacent tones used seem to be of the same importance and the dynamics remain unchanged until the next tone is reached (marked with horizontal brackets, see Figure 15).

2. The special approach to end tones in vocal lines through a number of preceding tones that surround this tone. This 'final formula' has to be achieved through a well-trained vocal that is strong enough to reach the ending tone without taking another breath. Possibly, it is to demonstrate not only the careful approach of end tones (marked by a star) but also to demonstrate vocal quality.

3. Throughout all the transcriptions, melismatic melodic progressions, leading to different pitches, can be observed. The melismatic movements of the vocal part do not exclude the named oscillations that can also ascend or descend in some inner parts of the vocal lines (their endings are marked with a star in Figure 15).

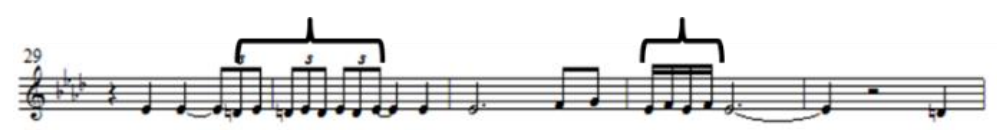

Bu- lan lah me- ngam- bang Pak
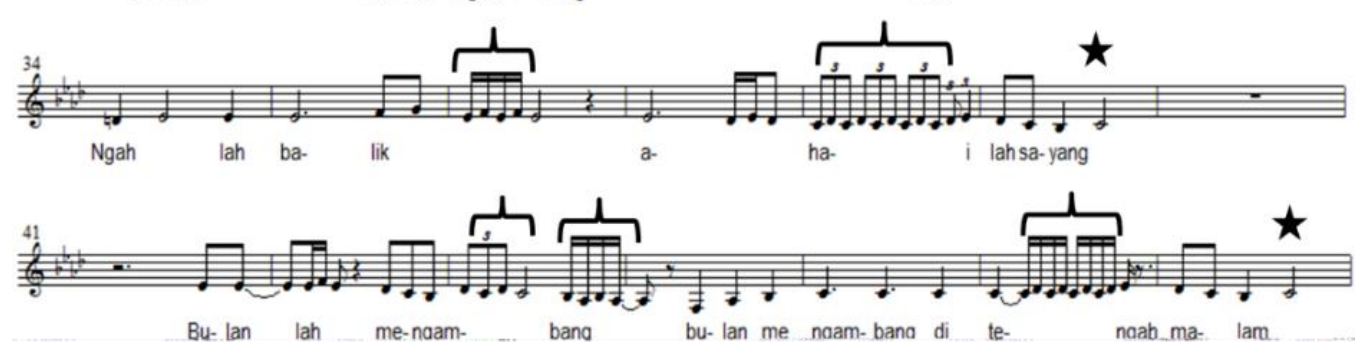

Figure 15. Typical Malay vocal melodic motions are shown in the first stanza of Pak Ngah Balik (A1-2) indicated by brackets above the specific melodic motion (transcription by the author).

Both the literature and the ghazal musicians' comments describe that the Malay ghazal has evolved into its current shape through the integration of foreign musical elements, mostly from Arab countries, India and Persia. Johari Arshad said that it's the "qasida from the Arabs, Indian singing style from India, and the Pantun from the Malay culture that makes the Malay ghazal. If any one of them is missing, then it is not a ghazal Johor" (2013: ARCPA2167 \& ARCPA2171). In the Malay ghazal tradition, students are not necessarily expected to acquire the basic knowledge of the maqamat or Hindustani raga or Persian dastgah and avaz, though the Malay musicians and literature imply that the Malay ghazal incorporates elements from Arab, Hindustani, and Persian music. The only 
knowledge of singing that Malay ghazal singers nowadays acquire in a thoughtful manner is the tarannum Al-Quran, which is based on the maqamat. This training of Malay singers may be reflected through the application of various techniques taken from Islamic singing styles, for instance, berzanji, marhaban, nasyid, tawashih, sholawat, and qasida all of which is practiced today. Since the Malay ghazal is relatively unbound to specific music traditions, Hindustani music elements were, and still are today, welcome in ghazal vocal renderings and instrumental interpretations.

\section{Non-vocal Malay Ghazal}

This ghazal noted in ARCPA2680 was recorded during fieldwork conducted in the National Arts Culture and Heritage Academy (ASWARA) in Kuala Lumpur. Norihan Saif was teaching it to the students as an example of an instrumental ghazal, though it is originally meant to be sung the same as other Johor ghazals. This ghazal was taught with no introductory piece.

Under specific conditions, the non-vocal Malay ghazal exists in order to introduce an entertaining event, to create an atmosphere among arriving guests and to support speeches as background music. This also applies to other music genres such as the dondang sayang, asli and joget. However, the case of an instrumental ghazal is interesting from the viewpoint of its melodic development in the absence of a singer. 


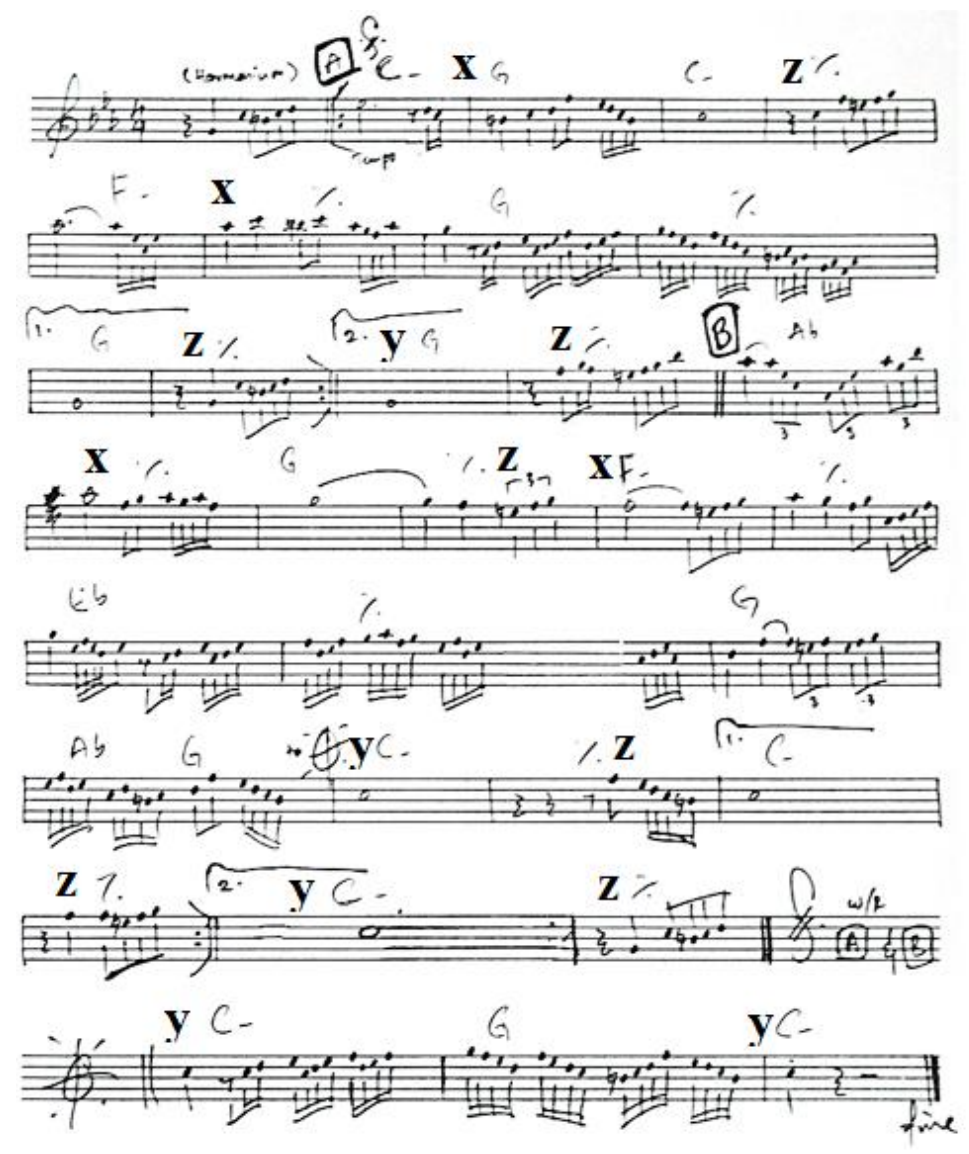

Figure 16. Score of Tambak Johor used as teaching material in the ghazal class at ASWARA 2012-2013, ARCPA1260G (as noted in the Appendix) (transcription by the author). The beginnings, endings, and transitions are marked with $\mathrm{x}, \mathrm{y}$, and $\mathrm{z}$ respectively.

At the class in ASWARA, the ghazal Tambak Johor was taught as an example of an instrumental ghazal. The harmonium executed the missing vocal melody by constructing a new melody into the vocal sections. However, the typical way of playing the entering melodic phrase and concluding long tones are still maintained throughout the ghazal, as marked in the transcription of one of the sung ghazals. With reference to the sung version of Tambak Johor, it is obvious that the harmonium in the instrumental version does not play the vocal melody that can be traced from recordings ${ }^{29}$ with a singer.

The Tambak Johor is taken into consideration for further analysis as follows. In the teaching situation, a score draft was handed over to the students that consisted of some phrases and important information that mainly allowed the harmonium players to reproduce the ghazal. 
The score indicates the beginnings ( $\mathrm{x}$ ), endings (y) and transitions (z) especially for those parts of the melody that are usually not played with a singer. The melody of the singer is replaced by improvisatory fragments of these parts, thus the entire harmonium melody changes to a more regularly structured type as illustrated in Figure 17:

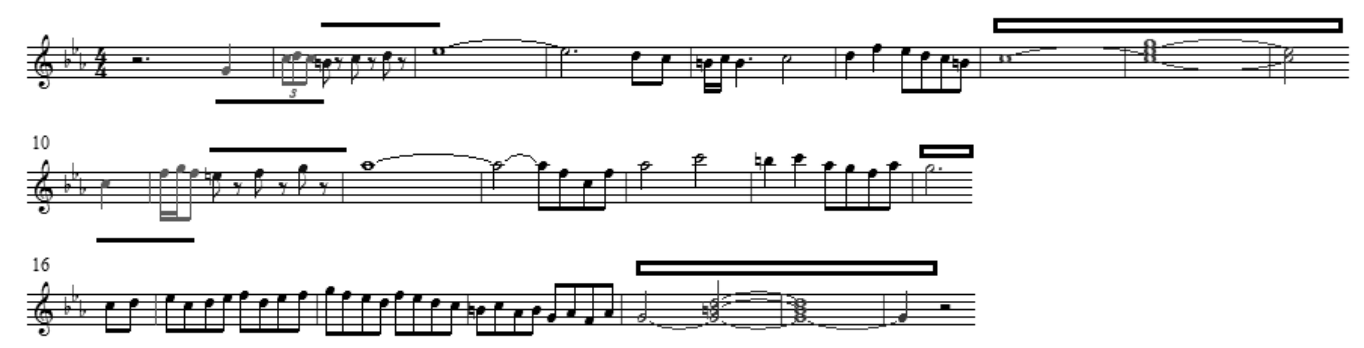

Figure 17. The harmonium melody played taking the score (Figure 12) as basic guide (underlined is a short introductory formula, followed by an ascending phrase with a line above; the rectangular box indicates the long sustain tones at the end of each melodic line). The simple sub-line is the introductory pattern, followed by an ascending pattern marked with a simple super-line. The final sustaining tone(s) are marked with a stretched box. These three elements are typical for harmonium playing in Malay ghazal (Meddegoda, 2015: 106) (transcription by the author).

Comparing advice given through the score and real playing, the range of individual interpretations becomes visible. This applies not only to the melodic lines but also to the rhythmic distribution of tones within a given time frame that indicates a good feeling for the meter though the harmonium player cannot fully adapt to the tabla player due to the absence of a cyclic rhythmic pattern in the tabla playing.

Interestingly, the instrumental version seems to be compatible with the sung version with regard to the meter and rhythmic structure. However, the melodic shapes of the harmonium part differ from the sung melody. For example, the beginning of the first stanza is sung as follows in Figure 18:

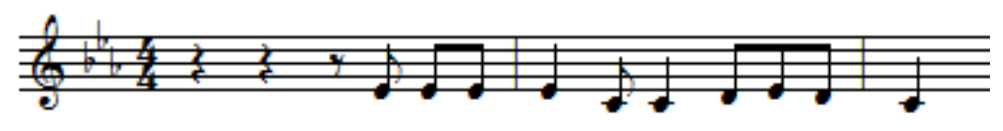

Figure 18. Transcription excerpt from ARCPA2678, the beginning of the first stanza of the piece Tambak Johor, vocal part (transcription by the author).

This melodic figure in Figure 18 is not played by the harmonium nor are other melodic sequences with a rather narrow range. The harmonium seems to be better used when playing wider ranges in broken chords (Meddegoda, 2015, 2016).

The history of the ghazal in India, Persia, and Arabian countries has seen the ghazal emerge as a poetry genre which was presented to an audience by chanting and singing. As a result, the ghazal has been developed in its manifold shapes as a singing genre in many local cultures. Later, the ghazal was available to a larger audience through records, 
cassettes, and CDs and also through radio, television and the internet. The listeners enjoyed not only the text meaning but also its musical content. Thus, ghazal instrumentals also became popular since most of the melodies were familiar and interesting to the listeners even without its textual meaning and in many cases, the ghazal lyrics were familiar to the listeners through the respective instrumental versions. Today, there are many instrumental ghazal melodies available and practiced in various private and public functions in the background while the participants are talking to each other or waiting until the main event starts. Sometimes, an instrumental ghazal is used as "muzak" (Lanza 2004) in elevators, waiting areas, lobbies, and some high-class restaurants in India. These instrumental ghazals, however, are not played only with Hindustani musical instruments but also with Western harmonic progressions and musical sounds which are included through electronic musical instruments generated by computer software.

In the case of the Malay ghazal performances, the lyrics are not meant to carry the substantial message, the musical sound including the voice is seen as the attraction to the local audience. The text in the ghazal Melayu does not directly reflect feelings of romance which are the main subject in popular ghazal poetry of ghazal genres in India and Persia. Therefore, the term ghazal is seemingly adapted to this particular ensemble due to the inclusion of the harmonium and tabla which were encountered by the Malays through Hindustani ghazal practices in Malaya.

However, it could also be that the Hindustani ghazal ensembles known to Malay musicians, which include an Urdu ghazal repertoire and Hindustani musical instruments, mainly the tabla and harmonium and/or sarangi, were adapted by the Malays and subsequently Hindustani elements were replaced with Malay and Malayised elements such as Malay pantuns, gambus, plucked lute, or other adopted musical instruments such as the violin, guitar, and tambourine.

The core idea of a ghazal performance has been transformed in Malaysia to experience mainly the aesthetics of the music rather than the aesthetics of poetry. In the history of secular music in the Malay world, most of the foreign music genres were adapted by Malays, not because they could enjoy the lyrics but mostly because they enjoyed the musical idea and sometimes the combination of music with dance. Another reason could be that the Sultan and other aristocrats preferred certain performances that were attributed to the colonizers. In an interview, Haji Jafar shared some experiences at the Sultan's palace of Johor:

The late Sultan Iskandar, he really loved kroncong so much and jazz music. He sometimes liked the ghazal but not as much he liked kroncong and jazz. At every birthday function, the officers arranged jazz and kroncong concerts. I am the one who proposed to the Sultan which singers will be taken. I give him a list, and then he says this one ok and this one not ok and so on. ${ }^{30}$

Malay ghazal was not so much important to the Sultan, however, as the more important the ghazal became to the lower ranks of Malay society. 
Seemingly, Malay aristocrats have preferred musical content rather than the text of secular music practices that were arriving from abroad. Music genres carrying Islamicoriented text are taken seriously by Malays; they are seen as falling into the category of appropriate music genres (Beeman, 2011; Jähnichen, 2012). Respectable lyrics that are applied to melodies may also not be completely understood due to the fact that these lyrics are mostly in the Arabic language (Rasmussen, 2010: 5). This kind of music practice is mostly adopted and respected from the viewpoint of Islam; nevertheless, Malays may not really enjoy them as an entertaining event and, therefore, would not include them in private celebrations or in leisure time activities. Thus, it can be assumed that keroncong, jazz, and the ghazal Melayu might have been preferred as they are enjoyable without paying much attention to the sung text.

Another aspect is that some Arabic, Persian or Urdu texts may carry special metaphors and hidden meanings (Qureshi, 1990) and therefore demand a deeper understanding of historical and cultural facts which may have been seen as an additional burden to the audience.

The Malay ghazal, to conclude, has so far no fixed compendium of stylized and formalized repertoire of lyrics. This observation leads to the insight that in many cases the vocal part is meant to carry the musical meaning rather than the lyrical, and that first of all the quality of the voice is a deciding criterion for successful performances. In instrumental ghazal versions, the quality of the voice is represented mainly through the leading melody instrument, which is the harmonium.

\section{Summary}

This paper takes a closer look at the exclusion and inclusion of ghazal lyrics after having explored the actual application of ghazal lyrics in some selected examples. ${ }^{31}$

Malay pantuns may have been refined during the adaptation process, though there is no evidence in the examined literature. The indication of refinement derives from the social function of Urdu ghazal texts that may have had an influence on the choice of pantuns that were used for Malay ghazal performances. Another aspect is the popularisation of the Malay ghazal with the use of locally adapted pantuns. Text and musical contents could have been compromised in a way that allowed a wider circle of the community to practice the Malay ghazal. Again, clear evidence in the literature is missing, except for the descriptions of Adibah Amin (1979). Later on the ghazal was practiced as a song contest as described by Pak Lomak (Haji Musa bin Yusof, 1953). However, this contest followed different rules than those of poetic symposia (mushaira) held during gatherings of noble aristocrats in North India. The aesthetics of singing varies accordingly.

From many possible elements that can be found in Hindustani ghazal and other Hindustani music genres, the choice of elements to be maintained in the Malay ghazal are quite limited. These are:

- Various raga elements can be detected in the Malay ghazal vocal melody. These elements are not reflected and terminologically unknown at all to Malay ghazal 
musicians but they can still be traced in vocal melodies. These detected ragas maintain one tonic, which means that the main fifth (Sa-Pa) applies as a frame for the entire melody.

- Kirwani, bhairavi and mishra bhairavi, ashawari, ahir-bhairav, shuddha bilawal, alhaiya bilawal, adana, darbari kanada, jounpuri, and ramkali are ragas from which traces could be found in the Malay ghazal melodies. However, the singers and musicians are not aware of these names or the ragas.

- Malay ghazal renderings may reflect some Hindustani musical elements which have influenced the musicality of Malay musicians through hearing and practicing Hindi film songs. Despite this, there is very little possibility that Malays have obtained deeper knowledge regarding raga and the meter of Hindustani music through hearing and imitating Hindi film music.

- A particular singing style called "Parsi" that primarily focussed on a specific embellishment of the melodic line can be observed. This singing style, transmitted orally over the past decades, imitates vocal parts performed in songs sung in the Parsi theatre. Another particular element is called "sarigamasinging" (Arshad, 2013; Rahman B., 2012) that refers to melodic ornaments resembling the gamak and taan in Hindustani classical music. Thus, they are not related to the Hindustani solfege syllables. Both stylistic features might be idealised through their use in Malay ghazal practices by outstanding performers such as Ramlah Adon, Ahmad Jusoh, Rosiah Cik (Jamie Cik, 2013) and Sharifah Aini.

- The range in which Malay ghazal is sung does not exceed one octave. But, the actual starting pitch is somewhat fixed through the fact that early harmoniums could not shift in pitch (Meddegoda, 2013). Therefore, ghazals were and are mainly played for a high pitched male or a lower pitched female voice. Male singers performing ghazals may have obtained singing skills from the model of qawwali singers. There is no evidence for it in the reviewed written source materials, however, the knowledge about these special features, that can also be observed in Hindustani ghazal, is transmitted orally from one musician to the next (Norihan, 2012-2014).

In summary, the process of adaptation and its outcome that has been documented in the selected ghazals confirms the existence of a discerning tolerance towards elements that are detached from their cultural environment, but still can become symbolic musical elements that can be identified as traces of Hindustani culture. The transformation does not cause their meaning, as given through the generating culture, to be entirely lost. Specific vocal ornaments, singing range and the dynamic strength in rendering long tones are still remarkable qualitative attributes that support, among others, a Hindustani legacy within the Malay ghazal. 


\section{Endnotes}

1"Qawwali is a recognized musical genre in the Indian subcontinent. It shares general traits with the light classical music of North India and Pakistan, but has unique characteristics related to its religious function. The term Qawwali itself applies both to the musical genre and the occasion of its performance, the devotional assembly of Islamic mysticsm or Sufism in India and Pakistan. The practice of Qawwali extends throughout Muslim centres of the Indian subcontinent, but its roots are North Indian" (Qureshi, 1986: viii).

${ }^{2}$ Malay term for a poem or poetry.

${ }^{3}$ Stanzas of four lines that follow a specific rhyme scheme. The pantuns exist in a number of other literary genres. They were appropriated for ghazal singing as they were originally made for other purposes.

${ }^{4}$ According to the Encyclopaedia Britannica accessible via http://global.britannica.com/EBchecked/topic/485544/qasidah

${ }^{5}$ Though a mutually supporting development of ghazal and qasida could be observed, both genres did obviously not derive from the same source.(Md. Nor \& Kaeh, 1985)

${ }^{6}$ Detailed explanations can be found in Md. Nor \& Kaeh (1985).

${ }^{7}$ This information is accessible via http://www.urdupoetry.com/novicenook/ ghazalelements.html. This page is maintained by Nita Awatramani and last updated on 12 Sep 2004.

${ }^{8}$ This information is accessible via http://www.urdupoetry.com/glossary.html. This page is maintained by Nita Awatramani and last updated on 31 March 2001.

${ }^{9}$ Ibid.

${ }^{10}$ This information is accessible via http://www.urdupoetry.com/novicenook/ ghazalelements.html. This page is maintained by Nita Awatramani and last updated on 12 Sep 2004.

${ }^{11}$ This information has been provided by Irfan 'Abid' (2001) in an online article. Accessible via http://www.urdupoetry.com/articles/art5.html.

${ }^{12}$ This information is accessible via http://www.urdupoetry.com/novicenook/ ghazalelements.html. The website is maintained by Nita Awatramani and last updated on 12 Sep 2004.

${ }^{13}$ Ibid. 
${ }^{14}$ Ibid.

${ }^{15}$ Ibid.

${ }^{16}$ Ibid.

${ }^{17}$ Ibid.

${ }^{18}$ Encyclopaedia Iranica. Accessible via http://www.iranicaonline.org/articles/search/ keywords:Divan.

${ }^{19}$ Translation into English (by Kanda, 2013: 153):

All my hopes stand belied,

No prospect is in sight!

Death will come when it will come,

Why does sleep not come at night?

I once could laugh at the state of my heart,

But nothing can make me laugh today.

To pray and penance is good, I know,

But my mind is not disposed this way.

There must be something that holds my tongue,

Not that I know not how to speak.

If you can't see my scalded heart,

Can't you, O healer, smell the burn?

I am in that obvious state,

A stranger to myself where I am.

${ }^{20}$ The idea of a pantun as a quatrain, a verse consisting of four lines, is somewhat inconsistent with the terminology used among Malay ghazal musicians. Some consider all four poetic lines divided into two vocal lines as one pantun, some think of it as twopart poems, thus a ghazal consisting of four pantuns (Haji Jafar, 2013). In order to avoid confusion, the musical unit in this paper is called 'stanza' while the term 'pantun' refers only to the poetic form. Further research has to follow regarding this matter.

${ }^{21}$ In Malaysia, by law, all Malays are Muslims.

${ }^{22}$ The choice of these ghazals was realized through a detailed selection process in which a representative number of musicians and singers was involved (Meddegoda, 2015: 85-97). Sri Mersing: Sri Mersing (ARCPA2261) was recorded by the author during his fieldwork in Johor on 11 June 2013 at Yayasan Warisan Johor Auditorium. This ghazal was sung by Abdul Rahman and accompanied by Mohamad Syafiq (gambus), Zainal Bin Talib (harmonium), Sheikh Malek Fuizal (tabla) and Kamaruz Zamad (guitar). This ghazal is originally an early composition of Pak Lomak (possibly 1924) that was later often transformed into other popular singing styles such as asli or inang (Norihan, 2016, Yayasan Warisan Johor, 1998: 6, 9). Pak Ngah Balik: This ghazal is sung by Wahid Tasmir for the ghazal collection titled 'Sri Muar Ghazal' which was published in 2005 by INSICTECH MUSCLAND SDN. BHD. The music 
arranger (gubahan) of this colloction is Saleh Hj Arshad and the ghazal Pak Ngah Balik as well as other ghazals of this compilation were accompanied by Yusof Vajuri (violin), Kamarudin A Rahim (guitar), Saidi Sariman (gambus), Aziz Abdullah (tabla), Salim Selamat (marakas), Ahmad Tahunddin A. Rahim (tamborin) and Saleh Hj Arshad (harmonium). Nasib Badan: This ghazal was sung by the author and recorded in RTM Johor on 13 June 2013 for broadcasting during the Hari Raya Celeberation in 2013. The ghazal was accompanied by the instrumentalists Razali Noor (tabla), Paiman HJ Ahmad (maracas), Yusof Bajur (violin), and Abdul Rashid (harmonium).

Sri Muar: This ghazal is sung by Hasnah Ismail for the ghazal collection titled 'Sri Muar Ghazal' which was published in 2007 by INSICTECH MUSICLAND. The music arranger of this collection is Saleh $\mathrm{Hj}$ Arshad. The ghazal Sri Muar as well as the other ghazals in this CD were accompanied by Salleh Hj. Arshad (Haromonium and violin), Kamarudin A. Rahman (guitar), A. Hamid (gambus), Aziz Abdullah (tabla), Hishamuddin Johari and Yusof Bajuri (marakas), and Zainal A. Rahim (tamborin). Sayang Musalmah: This ghazal was sung by Sharifa Aini accompanied by Bersama Orkestra RTM in 2012. The sound track was extracted from a video file that is available via: http://www.youtube.com/watch?v=ZNspwXzpV9Y. The choice of this example is guided by the idea to include a larger diversity of performance situations of Malay ghazal. The distribution of ghazal recordings through social networks is a common issue and serves not only actual updates but also the reference to audiovisually preserved recordings that cannot be experienced anymore as in the case of Sayang Musalmah performed by the late Sharifa Aini. Tambak Johor: This ghazal (ARCPA2680) was recorded during the fieldwork conducted in ASWARA, Malaysia. Norihan Saif was teaching this ghazal to the students as an example for instrumental ghazals though this ghazal is originally meant to be sung as other Johor ghazals.

${ }^{23}$ All transcriptions are made by the author.

${ }^{24}$ Pivotal lyrics are the lyrics given through the pure poetic form. In songs, these pivotal lyrics are enriched or extended through repetitions of words deriving from these pivotal lyrics and additional singing syllables. A poem is rarely consisting of the same text in all its details as the song lyrics that use that poem.

${ }^{25}$ The definition of a raga used here is not limited to a set of intervals. It includes all important features of ragas as extensively defined in literature by Bhatkhande, Vishnu Narayan (1968-73) in his Kramika Pustaka Malika.

${ }^{26} \mathrm{Sa}$ is usually the tonic and $P a$ the fifth above. That does not mean that $S a$ or $P a$ or both are always the main reference tones of any raga. These reference tones are called vadi and samvadi.

${ }^{27}$ ARCPA is the Audiovisual Research Collection for the Performing Arts at the Universiti Putra Malaysia, established since 2013. Unrestricted on-site access is possible at the Music Department of UPM. 
${ }^{28}$ Parsi theatre preceded Bangsawan and was one of the main sources for the later Bangsawan that used a number of music genres that were first known through Parsi theatre (Meddegoda, 2015).

${ }^{29}$ Accessible at Audiovisual Research Collection of Performing Arts (ARCPA2678) in Universiti Putra Malaysia.

${ }^{30}$ Haji Jafar and Chinthaka Prageeth Meddegoda (2013). Personal communication. Yayasan Warisan Johor. Retrieved from ARCPA02257 in Universiti Putra Malaysia.

${ }^{31}$ These examples were studied in course of a doctoral research from 2012 to 2015 at UPM. The author studied under supervision of Prof. Dr. Gisa Jähnichen.

\section{References}

Ahmad, R. (2007). Ghazal Melayu Johor. Johor Baru: Yayasan Warisan Johor.

Amin, A. (1979). Ghazal Music is Becoming Popular Again. New Straits Times Annual, Kuala Lumpur, 57-59.

Bausani, A. (1960). Ghazal ii in Persian Literature. The Encyclopedia of Islam, New Edition 1, Leiden: E. J. Brill.

Bausani, A. (1965). Ghazal ii in Persian Literature. The Encyclopedia of Islam, New Edition 2, 1033-1036. Leiden: E. J. Brill.

Beeman, W. O. (2011). Production, Hearing and Listening: Intentional Participation in Musical Culture in the Islamic World. Anthropology News, 52 (1), 11.

Benjamin, G. (2011). Music and the Cline of Malayness. A paper presented at 'Symposium on Thinking Malayness'. Research Institute for Languages and Cultures of Asia and Africa, Tokyo University of International Studies, 19-21 June 2004.

Retrieved on 24, September 2012 from http://class.cohass.ntu.edu.sg/Publications/Documents/Benjamin\%20Music $\% 20$ and\%20the\%20Cline\%20of\%20Malayness.pdf Unpublished.

Bhatkhande, V. N. (1968-73). Kramika Pustaka Malika. Hathras: Sangeet Karyalaya.

Braginsky, V., Anna S. (2008). A New Wave of Indian Inspiration:Translations from Urdu in Malay Traditional Literature and Theatre. Indonesian and the Malay World, 36 (104), 115-153.

Brakeley, T. C. (1949). Work Song. Standard Dictionary of Folklore, Mythology and Legend. New York: Annals of the New York Academy of Sciences. 
Encyclopaedia Britannica retrieved from http://global.britannica.com/ EBchecked/topic/485544/qasidah. Last retrieved 30 April, 2016.

Encyclopaedia Iranica. retrieved from http://www.iranicaonline.org/articles/search/ keywords:Divan. Last retrieved 30 April, 2016.

Farmer, Henry George (1965). Al-Farabi's Arabic-Latin Writings on Music in the Ihsa al-`ulum. New York: Hinrichsen Edition.

Gosvami, O. (1961). The Story of Indian Music: Its Growth and Synthesis. Bombay: Asia Publishing House.

Haji Musa, Y. [Pak Lomak] (1953). Ghazal Melayu (Gamat). Hand written manuscript by the author.

Irfan, A. (2001). Bah'r: The Backbone of Shaayari. Accessible via http://www.urdupoetry.com/articles/art5.html. Last retrieved 30 April, 2016.

Jähnichen, G. (2012). Al-Ghazali's Thoughts on the Effects of Music and Singing upon the Heart and the Body and their Impact on Present-Day Malaysian Society.

International Journal of Humanities and Social Sciences, 2 (9), 115-123.

Jähnichen, G. (2014). Maqam in Peripheral Cultures. Maqam: Historical Traces and Present Practice in Southern European Music. Ed. by Jürgen Elsner, Gisa Jähnichen \& Jasmina Talam. Newcastle upon Tyne: Cambridge Scholars Publishing, pp. 8-19.

Kanda, K.C. (1992). Masterpieces of Urdu Ghazal from the 17th to the 20th Century. New Delhi: Sterling Paperbacks.

Liaw, Y. F. (2013). A History of Classical Malay Literature. Singapore: Institute of Southeast Asian Studies.

Md. Nor, M.Y. and Kaeh, A. R. (1985). Puisi Melayu tradisi. Shah Alam: Penerbit Fajar Bakti.

Meddegoda, C. P. (2015). Musical Traces of Hindustani Culture in Malay Ghazal. PhD Dissertation. UPM. Serdang. . (2016). Instrumental Ghazal Melayu: A Functional Analysis. Studia Instrumentorum Musicae Popularis (New Series), 4. Edited by Gisa Jähnichen. Münster: MV-Wissenschaft, 187-202.

Meisami, J. S. (1998). Ghazal. Edited by Julie Scott Meisami and P. Starkey. Encyclopedia of Arabic Literature, 1, 249. 
Qureshi, R. (1969). Tarannum: The Chanting of Urdu Poetry. Journal of the society for Ethnomusicology, 13 (3), 425-468. . (1990). Musical Gesture and Extra-Musical Meaning: Words and Music in the Urdu Ghazal. Journal of the American Musicological Society, 43 (3), 457-497. . (1986). Sufi Music in India and Pakistan. Sound, Context, and Meaning in Qawwali. Cambridge: Cambridge University Press. . (1991). Whose music? Sources and contexts in Indic musicology. Comparative Musicology and Anthropology of Music: Essays on the History of Ethnomusicology. Edited by B. Nettl and P. Bohlman. Chicago: University of Chicago Press.

Rasmussen, A. K. (2010). Women, the Recited Qur'an, and Islamic Music in Indonesia. Berkeley: University of California Press.

Yayasan Warisan Johor (n.d.) Kajian Muzik Ghazal Melayu. Johor Baru: Yayasan Warisan Johor.

\section{Interviews}

Jamie Cik (2013), Johari Arshad (2013), Haji Jafar (2013), Norihan Saif (2012-2014, 2016). 